\title{
Rabies virus detection and phylogenetic analysis in samples from wild and domestic animals of Lithuania in 2007-2010
}

\author{
Ingrida Jacevičiene $\dot{~}^{1,2 *}$, \\ Vytas Tamošiūnas ${ }^{1}$, \\ Eugenijus Jacevičius ${ }^{2,3}$, \\ Mindaugas Morkūnas², \\ Jonas Milius ${ }^{4,5}$, \\ Gediminas Pridotkas ${ }^{2,3}$, \\ Vaclovas Jurgelevičius ${ }^{2}$ \\ ${ }^{1}$ State Research Institute Centre for \\ Innovative medicine, Vilnius, Lithuania \\ ${ }^{2}$ National Food and Veterinary \\ Assessment Institute, Vilnius, Lithuania \\ ${ }^{3}$ Department of Infectious Diseases, \\ Lithuanian University of Health Sciences, \\ Veterinary Academy, Kaunas, Lithuania \\ ${ }^{4}$ Department of Food Safety and Animal \\ Hygiene, Lithuanian University of Health \\ Sciences Veterinary Academy, Kaunas, Lithuania \\ ${ }^{5}$ State Food and Veterinary Service, \\ Vilnius, Lithuania
}

During the oral vaccination against rabies (ORV) in 2007-2010, phylogenetic analysis of rabies virus (RV) isolated from domestic and wild animals, was performed in the nucleoprotein $(\mathrm{N})$ gene region. In total, $66 \mathrm{RV}$-positive brain samples were analysed: 52 samples from wild and 14 from domestic animals. The investigation was carried out at the National Food and Veterinary Risk Assessment Institute. For confirmation, RV identification in the analysed brain samples $(\mathrm{n}=66)$ was performed by three methods: fluorescent antibody test (FAT), rabies tissue culture infection test (RTCIT) and reverse transcription polymerase chain reaction (RT-PCR). The results obtained by the three methods employed were similar: RV was identified in 66 samples of brain. The region of RT-PCR gene was amplified from $(n=66)$ positive brain samples and the obtained sequences of $362 \mathrm{bp}$ nucleotides were compared with the selected other sequences of rabies virus from the GenBank. The phylogenetic analysis of $\mathrm{N}$ gene from wild and domestic animals showed a close genetic relationship between the different RV isolates irrespective of species or regional origin. The obtained results indicate that all RV strains in Lithuania belong to the first RV genotype of the North-East European group.

Key words: rabies virus, phylogenetic, wild, domestic

\section{INTRODUCTION}

Rabies (lyssa, hydrophobia) is a viral zoonotic disease that causes encephalomyelitis and severe neurological disorders in domestic and wild animals as well as in humans. Rabies is an infectious disease transmitted by sick animals

\footnotetext{
* Corresponding author. E-mail: ijaceviciene@vet.lt
}

by a bite or slobbering of injured skin or, occasionally, mucous membrane. The rabies virus (RV) of Mononegavirales belongs to Lyssavirus genus of Rhabdoviridae family with an unsegmented, single-stranded, negative-sense (-)RNA genome. The Rhabdoviridae family includes rodshaped viruses infecting animals and humans. The spiral capsids of these viruses are enveloped in lipids. The capsid encloses a $12 \mathrm{~kb}(-) \mathrm{RNA}$ genome. The genome interacts 
with the basic capsid nucleoprotein $(\mathrm{N})$ developing a spiral structure of 30-35 coils with 40 sub-coils in each of them. The nucleocapsid is clad by amorphous matrix $\mathrm{M}$ protein layer. The nucleocapsid membrane is composed of phospholipid bilayers and glycoprotein. The RV genome codes for 5 proteins: nucleoprotein $(\mathrm{N})$, phosphoprotein $(\mathrm{P})$, glycoprotein $(\mathrm{G})$, polymerase $(\mathrm{L})$ and protein of intercellular substance (matrix protein M) [1,20]. Arrangement of these proteins and RNA genome predetermine the structure of rabies virus [20].

By polymerase chain reaction (PCR) in monoclonal antibodies, 7 genetic types of rabies viruses were identified: classical rabies virus (RV, genotype 1, serotype 1), Lagos bat virus (LBV, genotype 2, serotype 2), Mokola virus (MV, genotype 3, serotype 3), Duvenhage (DV, genotype 4, serotype 4), European bat virus (EBL 1, genotype 5, EBL 2, genotype 6) and Australian bat virus (ABV, genotype 7) [1].

In the Baltic countries - Lithuania, Latvia and Estonia - Lyssavirus commonly is identified in wild animals. The prevalence of rabies in the population of domestic and wild animals presents a threat for human health [21].

The prevalence of rabies in the Lithuanian populations of wild and domestic animals was investigated in 19942003 and identified in all regions: wild animals accounted for $67.38 \%$ and domestic animals for $32.62 \%$ of the total number of all cases. In 1994-2003, the risk of human infection with rabies was analysed in Lithuania and it was determined that about $8000-11000$ people injured by wild or domestic animals were vaccinated [15]. There were no cases of death among the vaccinated patients, two unvaccinated people died; this proves that vaccination against rabies is an effective preventive measure [15].

The goal of the present work was to perform a phylogenetic analysis of rabies viruses in wild and domestic animals in the region of nucleoprotein $(\mathrm{N})$ gene and determine the geographical type of RV circulation in 2007-2010.

\section{MATERIAL AND METHODS}

In 2007-2010, 66 RV-positive brain samples from different Lithuanian districts were collected and analysed according to geographical distribution and host species: red foxes $(\mathrm{n}=22)$, raccoon dogs $(\mathrm{n}=28)$, wolves $(\mathrm{n}=1)$, martens $(\mathrm{n}=1)$, dogs $(\mathrm{n}=6)$, cats $(\mathrm{n}=4)$ and cattle $(\mathrm{n}=4)$. All brain samples were kept at $-80^{\circ} \mathrm{C}$.

The RV investigation was carried out at the National Food and Veterinary Risk Assessment Institute (NFVRAI) using the standard methods recommended by the World Organization for Animal Health (OIE) and World Health Organization (WHO): the direct fluorescent antibody test (FAT) and the rabies tissue culture infection test (RTCIT) $[13,16,17]$. The reverse transcription (RT) and polymerase chain reaction (PCR) were also performed [18].
The direct Fluorescent Antibody Test (FAT). Antigenic analysis of RV was performed by direct FAT. The analysed material - brain tissue - was fixed on the object glass and tagged using fluoresceine isothiocyanate (FITC) antirabic polyclonal antibodies covalently bound to fluorochrome $[13,16]$. A specific interaction between the antigen and antibodies and fluorchrome radiance under ultraviolet radiation helped to detect the antigens. Commercial FITC (Bioveta, Czech Republic) against rabies was used according to manufacturer's instructions. The following controls were used for specific FAT: the FITC conjugate against rabies (positive) + analysed material (brain tissue) and FITC conjugate against rabies (negative) + analysed material (brain tissue). The rabies virus proteins were tagged to FITC. Under the green ultraviolet radiation, the light reflected by the analysed samples is well seen. Using the FAT method, the specific nucleocapsid protein was identified by the reflected light. The FAT was performed using a luminescent microscope (Nicon, Japan) in a dark room.

Rabies tissue culture infection test (RTCIT). The antigenic analysis was performed by inoculating N2a CCL-131 RV cells. The cells were stained using direct FAT [13]. For RTCIT, reference material - N2a CCL-131 (Neuroblastoma cell) - and positive control - rabies virus CVS-11 (ATCC VR 959) - were used (Challenge Virus Standard) [13, 16]. The reference material was provided by the EU Reference laboratory for rabies (ANSES, Nancy, France). After 48 hours of incubation at $37^{\circ} \mathrm{C}$, the inoculated cells N2a CCL-131 were fixed with acetone $80 \%$ and stained with FITC monoclonal antibodies against rabies (Fujirabio, USA). The obtained results were assessed using a luminescence inversion microscope (Leica, Germany) in a dark room. The result was positive when one or more fluorescent cells were detected in a well and negative when not a single fluorescent cell was found.

RNA extraction. RNA was extracted directly from the rabid animal's brain. RNeasy mini kit (Qiagen) was used according to manufacturer's instructions. Brain samples were homogenised in a RLT lysis buffer on a TissueLyserII machine. RNA was eluted with $70 \mu \mathrm{L}$ of RNase-free water and used immediately for PCR. The remaining RNA was stored frozen at $-20{ }^{\circ} \mathrm{C}$ for further investigation.

RT-PCR assay. RT-PCR was performed using a One Step RT-PCR kit (Qiagen). $5 \mu \mathrm{L}$ of RNA were used for

$25 \mu \mathrm{L}$ reactions. The reaction mixture contained $5 \mu \mathrm{L}$ of One Step RT-PCR buffer, $1 \mu \mathrm{L}$ of dNTPs each at a concentration of $10 \mathrm{mM}, 1 \mu \mathrm{L}$ of enzyme mix, $1 \mu \mathrm{L}$ of each primer - JW12(5'-ATGTAACACCYCTACAATG-3') and JW6DPL(5'-CAATTCGCACACATTTTGTG-3') both at a concentration of $20 \mathrm{mM}$, and $11 \mu \mathrm{L}$ of PCR grade water. Cycling was set to reverse transcription for $30 \mathrm{~min}$ at $50^{\circ} \mathrm{C}$, and 15 min denaturation at $95^{\circ} \mathrm{C}$, followed by 35 cycles of PCR with an initial denaturation for $30 \mathrm{~s}$ at $94^{\circ} \mathrm{C}$, annealing for $30 \mathrm{~s}$ at $49^{\circ} \mathrm{C}$, elongation for $1 \mathrm{~min}$ at $72^{\circ} \mathrm{C}$ and with the final 
extension for $10 \mathrm{~min}$ at $72{ }^{\circ} \mathrm{C}$. Both reaction composition and cycling conditions were previously described by Orlovska [18]. Primers were earlier described by P. Heaton [3]. Amplicons were visualised on a $1.5 \%$ agarose gel. The resulting PCR products were cleaned using 500 U SAP (Shrimp alkaline phosphatase, "Fermentas", Lithuania) and 10 U ExoI (Exonuclease I, "Fermentas", Lithuania) by incubation at $37^{\circ} \mathrm{C}$ for $15 \mathrm{~min}$ and inactivation of enzymes at $85^{\circ} \mathrm{C}$ for $15 \mathrm{~min}$. Consequently, PCR products were purified using Centri-Sep spin columns by Applied Biosystems. Sequencing was performed using BigDye Terminator v3.1 cycle sequencing kit by Applied Biosystems according to manufacturer's protocol.

Sequencing and phylogenetic analysis. All alignments were performed using Clustal W by Larkin et al. [8] with default settings. Phylogenetic and molecular evolutionary analyses were conducted using MEGA version 4 by Tamura et al. [19].

\section{RESULTS}

Analysis of rabies infection dynamics in wild and domestic animals in 2007-2010 showed a decreasing incidence of this disease (Table). The highest incidence of rabies infection was determined in the Lithuania-Belarus border zone (Fig. 1).The source of rabies virus was registered in the Eastern periphery of Lithuania: Švenčionys, Šalčininkai, Varėna and Zarasai districts (Fig. 1). This trend of epizootic process motivated phylogenetic investigations of antigenic and genetic characteristics of RV.

For comparison of FAT, RTCIT and PCR methods the same RV-positive brain samples of wild $(\mathrm{n}=52)-22$ red foxes, 28 raccoon dogs, 1 wolf and 1 marten - and domestic -6 dogs, 4 cats and 4 cows - animals were used. The sequences of rabies products obtained by FAT, RTCIT and RT-PCR yielded comparable results - RV. The geographical

Ta ble. Rabies infection dynamics in wild and domestic animals in Lithuania

\begin{tabular}{c|c|c|c}
\hline Year & $\begin{array}{c}\text { Wild animal infection rate } \\
(\mathbf{x} / \mathbf{n}), \%\end{array}$ & $\begin{array}{c}\text { Domestic animal infection rate } \\
(\mathbf{x} / \mathbf{n}), \%\end{array}$ & $\begin{array}{c}\text { Total } \\
(\mathbf{x} / \mathbf{n}), \%\end{array}$ \\
\hline 2007 & $312 / 1208(25.82)$ & $116 / 766(15.14)$ & $428 / 1974(21.68)$ \\
\hline 2008 & $48 / 1038(4.62)$ & $22 / 464(4.74)$ & $70 / 1502(4.66)$ \\
\hline 2009 & $50 / 851(5.87)$ & $14 / 292(4.79)$ & $64 / 1143(2.97)$ \\
\hline 2010 & $31 / 897(3.45)$ & $2 / 269(0.74)$ & $33 / 1166(2.83)$ \\
\hline
\end{tabular}

$\mathrm{x} / \mathrm{n}$ - infected animals / number of examined animal

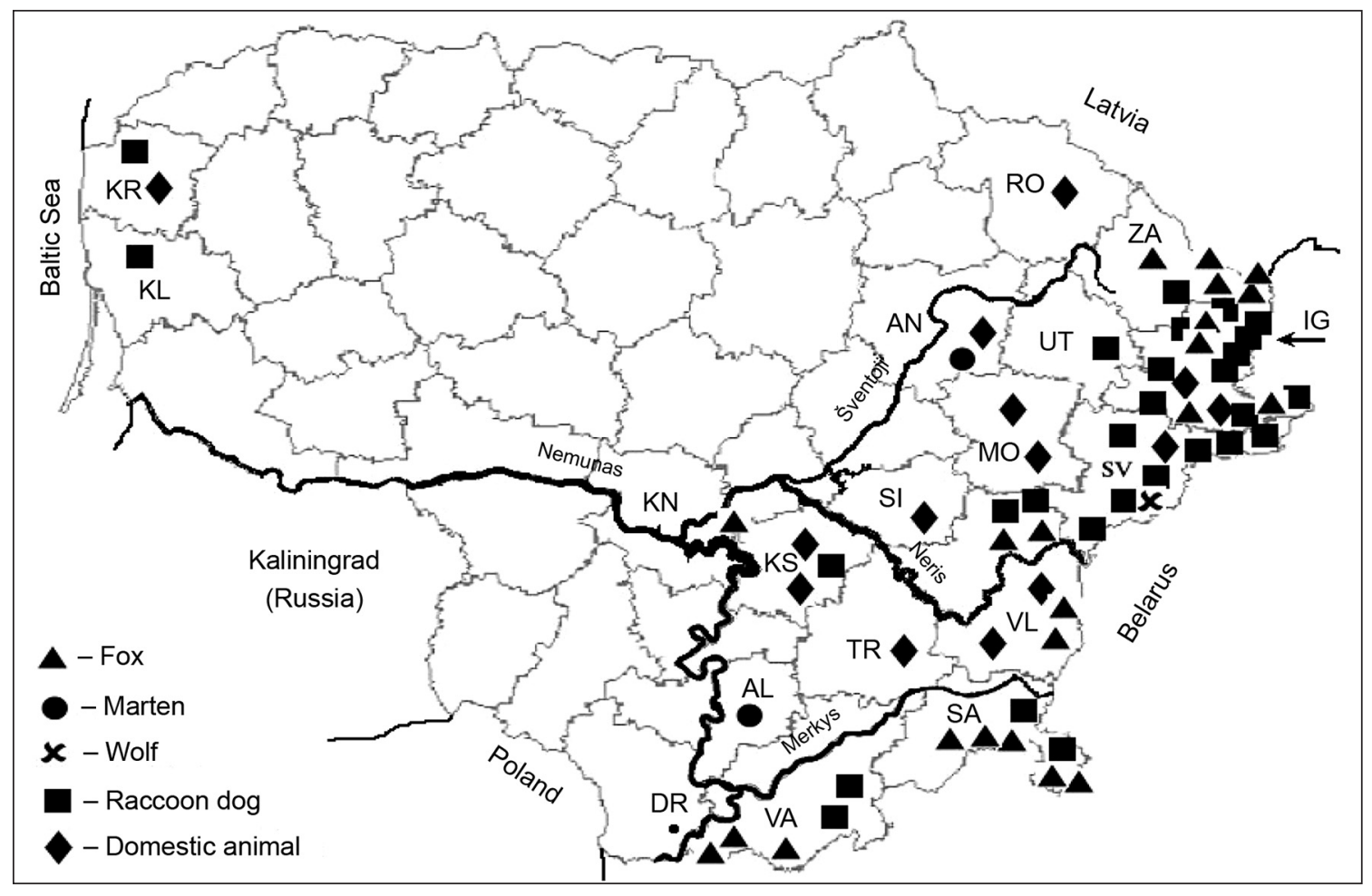

Fig. 1. The geographical distribution of rabies in different species of animals in Lithuania in 2007-2010. Abbreviations of districts: AL - Alytus, DR - Druskininkai, IG - Ignalina, KN - Kaunas, KS - Kaišiadorys, KR - Kretinga, MO - Molètai, RO - Rokiškis, SA - Šalčininkai, SI - Širvintos, SV - Švencionys, VA - Varèna, VL - Vilnius, TR - Trakai, ZA - Zarasai 
distribution of rabies in the investigated species of animals and the precise points of sampling were plotted in the map of Lithuania (Fig. 1). In terms of geographical distribution, the highest incidence of rabies infection was determined in the Lithuanian - Belarusian border zone. Rivers act as a natural barrier in the territory of Lithuania. The geographical boundary of rabies prevalence can be drawn along the Nemunas River which separates the Southern part of Lithuania and along the Neris and ventoji rivers separating the Eastern part of Lithuania in the Lithuanian - Latvian border zone (Fig. 1).

JW12 (5'-ATGTAACACCYCTACAATG-3') and JW6DPL (5'-CAATTCGCACACATTTTGTG-3') primers were used for sequencing of RT-PCR products. RT-PCR yielded RVpositive results. The multiple sequence alignment was performed using "Clustal W". The calculated percentage identity between nucleotide sequences showed that the brain samples of red foxes $(n=22)$, raccoon dogs $(n=28)$, wolves $(\mathrm{n}=1)$, martens $(\mathrm{n}=1)$ dogs $(\mathrm{n}=6)$, cats $(\mathrm{n}=4)$ and cattle $(\mathrm{n}=4)$ collected in Lithuania in 2007-2010 were genetically comparable (97-100\%) (Fig. 2). For geographical comparison, sequences of viruses circulating in the neighbouring countries were chosen $[2,6,7,10,21,22,23]$.

Phylogenetic analysis of RV circulating in Lithuanian red foxes $(\mathrm{n}=22)$ showed that $\mathrm{RV}$ isolates from these animals in the region of $\mathrm{N}$ gene were also phylogenetically similar to those of raccoon dogs $(n=28)$, wolves $(n=1)$, martens $(\mathrm{n}=1) \operatorname{dogs}(\mathrm{n}=6)$, cats $(\mathrm{n}=4)$ and cattle $(\mathrm{n}=4)$. For comparison, the identical strains of RV sequences from Belarus, Poland, Estonia, Latvia and Russia were used (Fig. 2). RV nucleotide sequences from the GenBank, which represent the sequences of sub-groups of RV circulating in Europe, were used for phylogenetic analysis and tree construction $[2,6,7,10,21,22,23]$.

\section{DISCUSSION}

Rabies is one of zoonoses able to cause serious health problems in Lithuania. Analysis of results obtained by FAT and RTCIT showed that in 2007-2010, foxes (Vulpes vulpes) and raccoon dogs (Nyctereutes procyonoides) were the main sources of rabies and a hazard for domestic animals. The present investigation showed that the highest prevalence of rabies in wild and domestic animals is characteristic of Eastern Lithuania (Fig. 1). In 2010, in the group of wild animals, rabies circulated among foxes (3.10\%) and raccoon dogs $(4.15 \%)$ whereas in the group of domestic animals its prevalence was low; only $0.74 \%$. It was observed that in 2007-2010, the number of rabies infections decreased in Lithuania. The curve of the incidence of rabies since 2007 has been falling [5]. The decreasing incidence of rabies can be accounted for by the prevention measures applied since 2006, i. e. oral vaccination against rabies (ORV). For the overall ORV in the territory of Lithuania, vaccine Lysvulpen (Bioveta, Check Republic) composed of attenuated rabies virus of SAD Berne strain is used [11]. Comparison of epizootic situation of rabies in Lithuania in 2003-2007 among different species of wild animals showed its highest prevalence in raccoon dogs (72.81\%) [5]. Prevalence in other species of wild animals was lower: foxes (59.28\%), martens (39.59\%), ferrets (24.33\%) and other wild animals (15.45\%) [4]. When foxes are infected with RV, the number of the individuals in the population decreases to a critical concentration of susceptible animals per unit area creating conditions for persistent transmission of rabies virus [17]. In such cases, the incidence of rabies naturally decreases. However, the population increases with its strengthening immunity and again the number of susceptible individuals grows up; especially in summer among the cubs [17]. In 2007-2008 the number of raccoon dogs infected with rabies decreased as a result of ORV with Lysvulpen vaccine. This leads to a conclusion that oral vaccination programs are efficient in combating rabies in the population of raccoon dogs [5]. ORV of wild animals, carried out in Lithuania on a regular basis since 2006 till 2010, contributed to a considerable reduction of the number of RV-positive cases. Eradication of rabies in wild animals would prevent the spread of this disease among domestic animals. The successful ORV of wild animals is expected to help eradicate this dangerous infectious disease both in wild and domestic animals. Success of ORV depends on a few factors: definite vaccination territory, mode of distribution of baits with vaccine, number of baits, properties of vaccine and effectiveness of the program [9]. Presumably, the success of ORV in Lithuania was predetermined by the fact that this program was simultaneously implemented by other Baltic countries [9].

Analysis of the obtained results showed that $\mathrm{N}$ gene sequence of RV in wild and domestic animals together with RV strains in the neighbouring countries form clearly defined phylogenetic branches in the phylogenetic trees (Fig. 2). Phylogenetic analysis of RV N gene 362 bp in Lithuanian populations of wild and domestic animals showed that the Lithuanian strains belong to the North East European (NEE) sub-group. The RV strains of the neighbouring countries are grouped together with the Lithuanian ones without any species or definite geographical determination proving the reported results of other research works. Phylogenetic analysis did not reveal for certain whether the red foxes were the source of rabies virus and transmitted it to raccoon dogs or raccoon dogs later transmitted them to foxes [2]. The strain belonging to the NEE geographical subgroup occurs in the region where the fox population is the largest, i.e. shows density of susceptible hosts and proximity of donors and new host species are the main ecological factor in determining $\mathrm{RV}$; perhaps the NEE strain confines to this species $[1,2]$. 


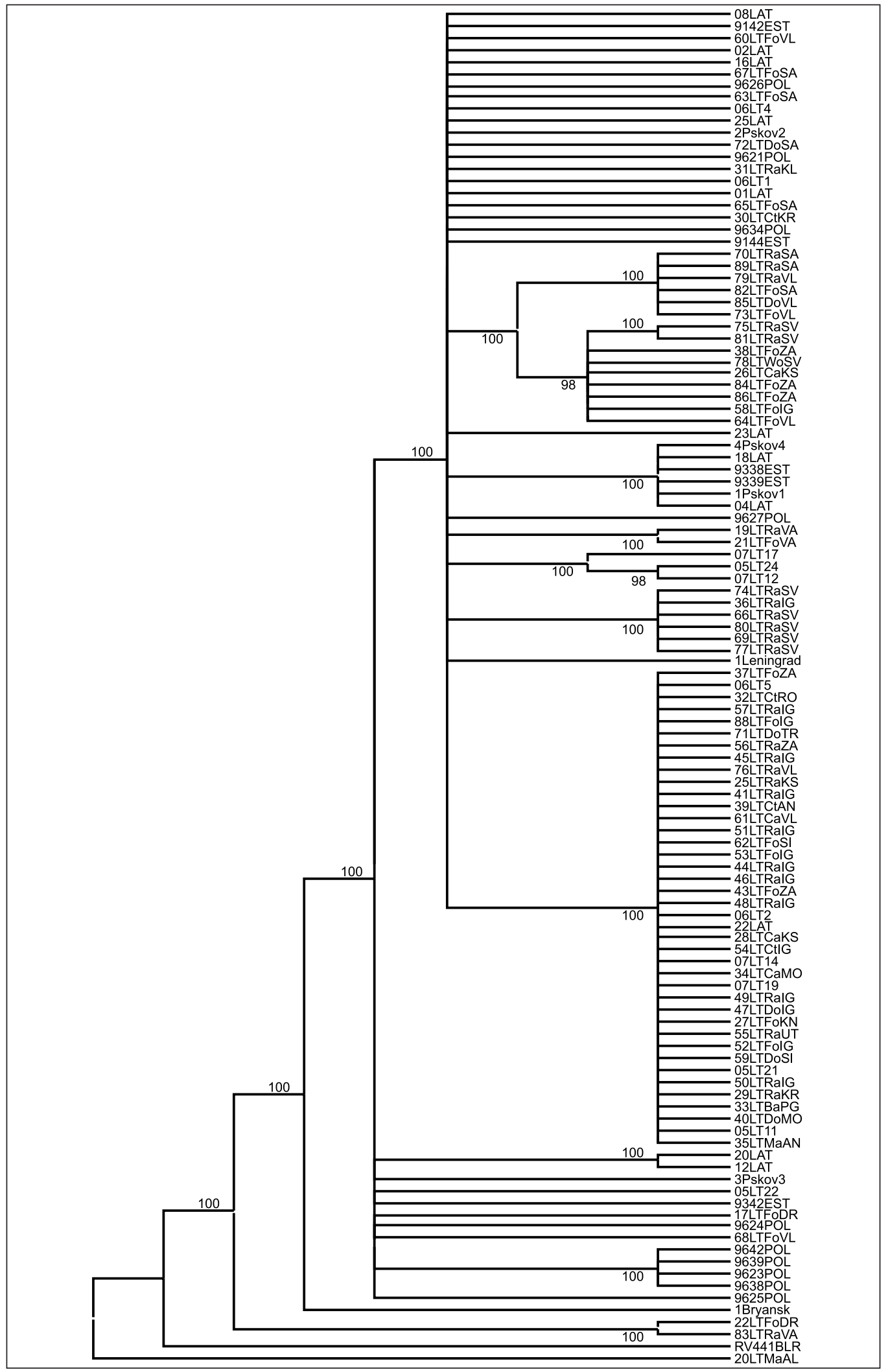

Fig. 2. Phylogenetic tree: phylogenetic analysis of RV N gene 362 bp circulating in the Lithuanian populations of wild and domestic animals. Maximum parsimony trees were drawn using "Clustal W" aligned sequences and MEGA4 package. Statistically significant 70\% cutoff was chosen for consensus trees. Phylogenetic tree of classical rabies nucleoprotein (N) sequences. Abbreviations: LTFoSA - Lithuania fox Šalčininkai, LT - Lithuania; animal species: Cat - Ca, Cattle - Ct, Dog - Do, Fox - Fo, Marten - Ma, Raccoon dog - Ra, Wolf - Wo; districts: Alytus - AL, Anykščiai - AN, Druskininkai - DR, Ignalina - IG, Kaunas - KN, Kaišiadorys - KS, Kretinga - KR, Molètai - MO, Rokiškis - RO, Šalčininkai - SA, Širvintos - SI, Švenčionys - SV, Utena - UT, Varèna - VA, Vilnius - VL, Trakai - TR, Zarasai - ZA) 
The RV isolates from wild and domestic animals were phylogenetically akin in identity to the sequences of nucleotides (98\%). This implies a direct transmission of viruses in the mentioned animal species and a common circulation of the agent in these populations [22]. Small differences between nucleotides imply that RV in red foxes, raccoon dogs and other wild and domestic animals is not absolutely homogeneous. The present investigation showed that a certain heterogeneity of nucleotide sequences can also be observed within the populations of other wild and domestic animals (Fig. 2).

Analysis of the epizootic situation in the territory of Lithuania in 2005-2006 (before ORV) prompted a phylogenetic investigation of RV [22]. Analysis of the sequences of $\mathrm{N}$ gene has showed that the Lithuanian RV strains belong to the geographical NEE sub-group [22, 23]. Based on the results obtained in 2007-2010 (ORV period) by phylogenetic analysis of $\mathrm{N}$ gene of the antigen, it can be concluded that there is its close geographical relationship among the neighbouring countries: Estonia, Latvia, Belarus and Poland.

Received 5 March 2011 Accepted 17 May 2011

\section{References}

1. Bourhy H, Kissi B, Tordo N. Molecular diversity of the lyssavirus genus. Virology 1993; 194: 70-81.

2. Bourhy H, Kissi B, Audry L, Smreczak M, SadkowskaTodys M, Kulonen K, Tordo N, Zmudzinski JF, Holmes EC. Ecology and evolution of rabies virus in Europe. J Gen Virol 1999; 80: 2545-57.

3. Heaton PR, Johnstone P, McElhinney LM, Cowley R, O'Sullivan E, Whitby JE. Heminested PCR assay for detection of six genotypes of rabies and rabies-related viruses. J Clin Microbiol 1997; 35: 2762-6.

4. Jaceviciene I, Jacevicius E, Tamosiunas V, Milius J, Lukauskas K, Pridotkas G. The efect of the oral vaccination of foxes against rabies by immunological tests. Vet Med Zoot 2008; 43: 30-7.

5. Jaceviciene I, Jacevicius E, Tamosiunas V, Pridotkas G, Milius J, Lukauskas K. Immunological investigation of rabies virus and oral vaccination effectiveness in raccoon dog population in Lithuania. Vet Med Zoot 2010; 49: 37-43.

6. Kissi B, Tordo N, Bourhy H. Genetic polymorphism in the rabies virus nucleoprotein gene. Virology 1995; 209 : 526-37.

7. Kuzmin IV, Botvinkin AD, McElhinney LM, Smith JS, Orciari LA, Hughes GJ, Fooks AR, Rupprecht CE. Molecular epidemiology of terrestrial rabies in the former Soviet Union. J Widl Dis 2004; 40: 617-31.
8. Larkin MA, Blackshields G, Brown NP, Chenna R, McGettigan PA, McWilliam H, Valentin F, Wallace IM, Wilm A, Lopez R, Thompson JD, Gibson TJ, Higgins DG. ClustalW and ClustalX version 2. Bioinformatics 2007; 23: 2947-8.

9. Niin E, Laine M, Guiot AL, Demerson JM, Cliquet F. Rabies in Estonia: Situation before and after the first campaigns of oral vaccination of wildlife with SAG2 vaccine bait. Vaccine 2008; 26: 3556-65.

10. Mansfield KL, Racloz V, McElhinney LM, Marston DA, Johnson N, Ronsholt L, Christensen LS, Neuvonen E, Botvinkin AD, Rupprecht CE, Fooks AR. Molecular epidemiological study of Arctic rabies virus isolates from Greenland and comparison with isolates from throughout the Arctic and Baltic regions. Virus Res 2006; 116: 1-10.

11. Matouch O, Vitasek J, Semerad Z, Malena M. Elimination of rabies in the Chech Republic. Dev Biol 2006; 125: 141-3.

12. McElhinney LM, Marston D, Johnson N, Black C, Matouch O, Lalosevic D, Stankov S, Must K, Smerczek M, Zmudzinski JF, Botvinkin A, Aylan O, Vanek E, Cliquet F, Muller T, Fooks AR. Molecular epidemiology of rabies viruses in Europe. Dev Biol (Basel) 2008; 125: $17-28$.

13. Meslin FX, Kaplan MM, Koprowski H. Laboratory techniques in rabies. WHO, Geneva, 1996; 4th ed., 1-83.

14. Milius J, Jacevicius E, Tamosiunas V, Lukauskas K. Rabies among wild and domestic animals in Lithuania in 1993-2002: epizootiology, diagnosis and vaccination. Bull Vet Inst Pulawy 2004; 48: 195-200.

15. Milius J, Razmuviene D, Jacevicius E, Tamosiunas V, Lukauskas K. Epidemiological situation of rabies in Lithuania in 1994-2003. Vet Med Zoot 2004; 49: 11-8.

16. OIE, Manual of Diagnostics Tests and Vaccines for Terrestrial Animals. Rabies, 2008; 2.1.13: 304-23.

17. OIE, Multiannual animal diseases status. Europe / Rabies, 2002: 1-12.

18. Orlowska A, Smreczak M, Trebas P, Zmudzinski JF. Comparison of real-time PCR and heminested RT-PCR methods in the detection of rabies virus infection in bats and terrestrial animals. Bull Vet Inst Pulawy 2008; 52: 313-8.

19. Tamura K, Dudley J, Nei M, Kumar S. MEGA4: Molecular Evolutionary Genetics Analysis (MEGA) software version 4.0. Mol Biol Evol 2007; 24: 1596-9.

20. Tordo N, Poch O, Ermine A, Keith G, Rougeon F. Walking along the rabies genome: is the large G-L intergenic region a remiant gene? Proc Natl Acad Sci 1986; 83: 3914-8.

21. Vanaga S, van der Heide R, Joffe R, Vander Poel WH. Rabies in wildlife in Latvia. Vec Bor Zoon Dis 2003; 3: 117-24. 
22. Zienius D, Sajute K, Zilinskas H, Stankevicius A. Phylogenetic Analysis of the Rabies Virus N-coding Region in Lithuanian Rabies Isolates. Acta Vet Brno 2009; 78: 273-80.

23. Zienius D, Zilinskas H, Sajute K, Stankevicius A. Comparative molecular charaterisation oh the rabies virus in the Lithuanian raccoon dog population. Bull Vet Inst Pulawy 2009; 53: 179-82.

Ingrida Jacevičienė, Vytas Tamošiūnas, Eugenijus Jacevičius, Mindaugas Morkūnas, Jonas Milius, Gediminas Pridotkas, Vaclovas Jurgelevičius

\section{LAUKINIỤ IR NAMINIỤ GYVŪNŲ PASIUTLIGĖS VIRUSO NUSTATYMAS IR FILOGENETINĖ ANALIZĖ LIETUVOJE 2007-2010}

\section{Santrauka}

Oralinès vakcinacijos prieš pasiutligę (ORV) laikotarpiu 2007$2010 \mathrm{~m}$. atlikome laukinių ir naminių gyvūnų pasiutligès viruso (RV) filogenetinę analizę nukleoproteino $(\mathrm{N})$ geno regione. Iš viso buvo analizuoti 66 teigiami RV galvos smegenų mèginiai: 52 laukinių ir 14 naminių gyvūnų. Tyrimai atlikti Nacionaliniame maisto ir veterinarijos rizikos vertinimo institute. RV identifikavimui naudojome tris tyrimo metodus: fluorescuojančių antikūnų tyrimą (FAT), pasiutligės viruso išskyrimą iš audinių (RTCIT) ir atvirkštinès transkripcijos ir polimerazès grandininę reakciją (AT-PGR). Skirtingų tyrimo metodų rezultatai buvo vienodi: 66 mèginiuose buvo identifikuotas RV. AT-PGR N geno regionas buvo amplifikuotas iš 66 teigiamų smegenų mèginių, o gautos 362 bp nukleotidų sekos palygintos su atrinktomis kitomis pasiutligès viruso sekomis iš esančio „GenBank“. Mūsų atlikta laukinių bei naminių gyvūnų filogenetinè $\mathrm{N}$ geno analizè atskleidè glaudų genetinị ryši tarp skirtingų RV izoliatų; rūšinis ar regioninis specifiškumas nenustatytas. Gauti rezultatai leidžia teigti, kad visos Lietuvos RV padermès priklauso pirmam pasiutligès genotipui - Šiaurès Rytų Europos grupei (NEE).

Raktažodžiai: pasiutligès virusas, filogenezè, laukiniai, naminiai 